Panu KARJALAINEN

Matti HAPPONEN

Piotr BIELACZYC

Rafat SALA

Jakub DZIDA

Toni KINNUNEN

Pekka MATILAINEN

Maria E. MESSING

\title{
An evaluation of particle oxidation catalyst (POC) performance and a study of particle formation for sulphur containing diesel fuels
}

\begin{abstract}
This paper describes and analyses the overall impact of fuel sulphur content on particulate oxidation catalyst (POC) performance, focusing mainly on particulates emission reduction and the ability to regenerate. Studies were carried out for diesel fuels containing different levels of sulphur, covering the range from 6 to 340 parts per million. The results presented in this paper give an outlook on specific issues and problems associated with POC application when running on fuels containing high sulphur level. The test methodology was experimentally established and then applied for POC catalysts to run on different sulphur level fuels. Each fuel was tested on an identical fresh POC sample. It was observed that the Fuel Sulphur Content (FSC) significantly affects catalyst conversion efficiency, as well as the particle size distribution. It also has a remarkable influence on particulate matter (PM) mass accumulation inside the POC and on the ability of the POC to regenerate passively. Regarding the latter aspect, $\mathrm{NO}_{2}$ formation was also determined. Extended test results and analyses presented in this paper are presented in SAE technical paper 2012-01-0366 [1].
\end{abstract}

Key words: particle oxidation catalyst (POC), fuel sulphur content, particulate matter reduction, regeneration

\section{Introduction}

Particulate matter emitted from internal combustion engines can affect human health [2-6] and the environment by interfering with the climate and ecosystems. Among others, the particulate matter (PM) present in diesel exhaust is of special concern because, due to their respirable size, the particles can penetrate deep into human lungs, affecting health; see e.g. [7 - 9]. Moreover, vehicular particle emissions are generated in our immediate environment, meaning that millions of people are exposed to these emissions on a daily basis. However, the harmful characteristics and affecting mechanisms of these pollutants are unclear.

PM emitted in diesel exhaust is a complex mixture of carbonaceous soot, unburned fuel and lubricating oil, and perhaps the products of fuel pyrolysis reactions. Particulate matter can be both solid and liquid; typically PM includes four fractions of diesel particulates: (1) solid soot, (2) SOF (soluble organic fraction; heavy hydrocarbons), (3) sulphur compounds and (4) ash. For modern engines, sulphur content is one of the fuel properties which has the greatest influence on particulates [10, 13]. Particulate emissions of diesel engine exhaust are a function of a number of parameters, including: engine type, engine operating conditions, and fuel and lubricant oil composition [10]. The size distribution of submicron diesel exhaust particles can typically be divided into two separate modes called the accumulation mode (AM) and the nucleation mode (NM) [15]. The accumulation mode consists of solid agglomerated soot particles which can bear volatile or semivolatile components (e.g. sulphur compounds, water, hydrocarbons) on their surfaces [15]. Nucleation mode particles have been commonly reported to consist of water, sulphuric acid and hydrocarbons. Several studies have indicated that nucleation mode particles are semi-volatile and that formation of the particles occurs when the exhaust gas is cooled and diluted in the atmosphere $[11,16,17]$. Other studies have also indicated that the sulphur from fuel and lubricant oil have a driving role in the particle formation process. However, some recent studies [18, 19] have indicated that nucleation mode particle formation can also take place without the sulphur driven process, so that the nuclei of nucleation mode particles are already formed under high temperature conditions.

Diesel vehicles are typically equipped with an exhaust aftertreatment system consisting of a diesel oxidation catalyst (DOC) and/or a diesel particle filter (DPF). The oxidising DOC can affect the semivolatile exhaust particle fraction both through hydrocarbon oxidation and because it usually promotes the conversion of $\mathrm{SO}_{2}$ to $\mathrm{SO}_{3}$. $\mathrm{SO}_{3}$ reacts with water molecules, forming sulphuric acid. Furthermore, based on modelling studies [20,21], the sulphuric acid and water can nucleate when the exhaust gas cools and dilutes in the atmosphere, or these molecules can condensate on the surfaces of soot particles. With a DOC installed, the semivolatile nucleation mode exists at high load and high FSC, even though no nucleation mode was measured without an after-treatment system installed [11, 17, 22, 23].

Many countries with developing economies have become significant and growing contributors to sulphur containing particulate emissions as there are many high-FSC (fuel sulphur content) fuels in use. In many cases, a high-efficiency Diesel Particulate Filter (DPF) with a wall flow design cannot be used 
in conditions with high sulphur level fuels. Moreover, its application is less cost efficient than a Particulate Oxidation Catalyst's (POC) [24, 25]. APOC, combined with a Diesel Oxidation Catalyst (DOC) placed upstream, is a significant emissions control technology used to reduce the PM in those applications, and also typically to meet Euro 3 and Euro 4 emission limits. The POC system is a flow-through passive self-regenerating and maintenance-free partial Diesel particulate filter. In the worst case scenario, there is a high sulphur fuel in use and the engine is running at low load (low exhaust temperature) for an extended period without phases allowing the passive system to operate. This scenario was targeted for simulation in this study, illustrating the differences between three fuel sulphur content levels and low driving speeds, as encountered under urban driving conditions in major cities in India and China with rural high-FSC fuels (as high as 2500 ppm S).

\section{Laboratory facilities}

Studies were performed on an engine test bed with an eddy-current dynamometer, equipped with a number of measuring channels with a $1 \mathrm{~Hz}$ acquisition rate. Pressure sensors installed both upstream and downstream of the POC system permitted determination of the soot loading as well as the rate of $\mathrm{POC}$ regeneration during the test. The temperature sensors, which were installed close to the pressure sensors, were very closely observed for any gas temperatures fluctuation which could strongly interrupt soot collection inside the POC system. A Horiba gas analyser was also embedded into the test stand to measure gaseous compounds, together with an AVL Smoke Meter for particulate emission monitoring.

In order to measure particle reduction efficiency of the POC system, the sample, taken upstream or downstream of the aftertreatment system, was diluted using two stage dilution (ejector diluters). In the first stage the dilution air temperature was $250^{\circ} \mathrm{C}$ and the dilution ratio (DR) was approximately 10 . In the second stage, the dilution air temperature was equal to room temperature $\left(25^{\circ} \mathrm{C}\right)$ and the DR was approximately 8 . To study the effects of FSC on volatile particle fraction and to mimic real-world exhaust particle formation [26], the exhaust sample was diluted using a porous tube diluter (PTD) [27, 28]. The PTD dilution system has been used widely in nucleation

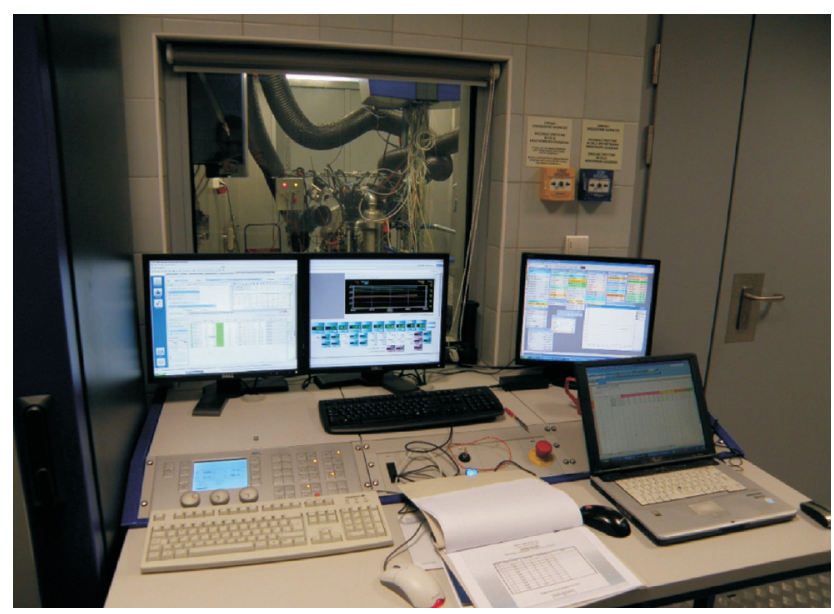

Fig. 1. Test bed control panel mode particle studies $[11,18,26,28]$. In the PTD, the dilution air temperature was $30^{\circ} \mathrm{C}$, the DR was set to 12 and the relative humidity of the dilution air was below 5\%. After passing through the PTD, the diluted sample was led into an ageing chamber and secondary dilution was conducted by an ejector (DR 8, room temperature). The carbon dioxide concentration was measured in the raw exhaust and at two other locations in the sampling setup. Final dilution ratio corrections were performed according to these measured $\mathrm{CO}_{2}$ concentrations. The particle size distributions were measured with an SMPS (DMA 3081 and UCPC 3025, TSI Inc.) [26, 27].

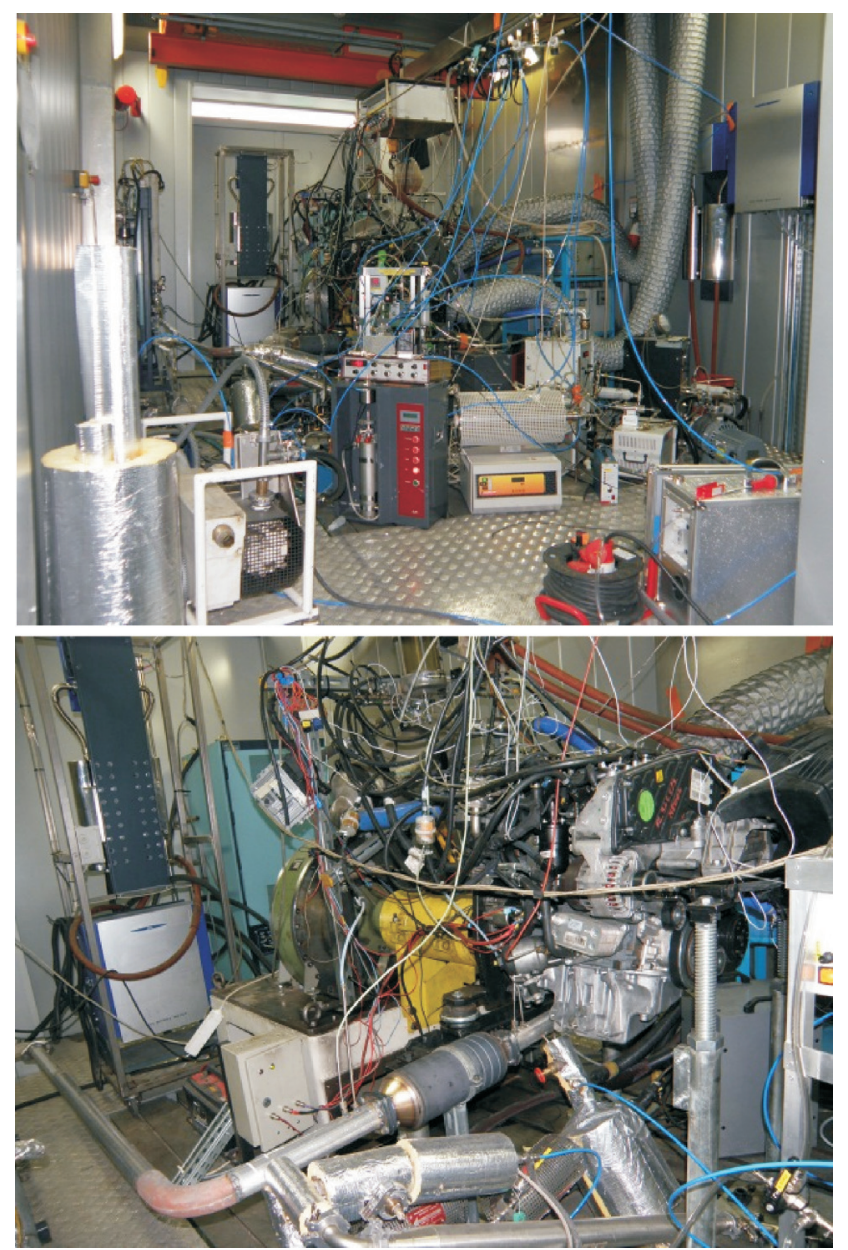

Fig. 2. Test bed layout

\section{Measurement approach}

Three identical samples of DOC+POC systems were used to test three different fuels containing $6 \mathrm{ppm}, 65 \mathrm{ppm}$ and 340 ppm of sulphur, hereafter referred to as: S6, S65 and S340. The engine used for testing was a passenger car diesel engine complying with the Euro 4 emission standard with 1.91 of displacement and a maximum output power of 150 HP. The test profile used for the comparison study lasted $49 \mathrm{~h}$ and consisted of two phases, determined according to the smoke number (FSN) and the inlet DOC+POC exhaust gas temperature as crucial factors:

- Soot loading phase $-48 \mathrm{~h}$ of engine operation at a low load point with a maximum exhaust temperature of $250{ }^{\circ} \mathrm{C}$ (to 
simulate urban driving conditions in major cities in India and China).

- Regeneration phase $-1 \mathrm{~h}$ of engine operation at a medium load point with a maximum exhaust temperature of $400^{\circ} \mathrm{C}$ (to simulate conditions where regeneration initiates following a long loading period).

The test cycle was run for each fuel of different sulphur content. The loading phase was performed in order to evaluate the amount of soot collected in the POC as a function of fuel sulphur content. Loading of the POC system was possible due to the low exhaust temperature (below $250{ }^{\circ} \mathrm{C}$ ) to avoid regeneration and FSN values in the range 0.35 to 0.65 (depending on fuel type) which were reasonable values for such a low engine load. Moreover, gaseous emission measurement permitted evaluation of the influence of the fuel sulphur content on catalyst efficiency. Each loading phase was commenced with the POC empty of soot, which was weighed, and continued with the soot loading process. The monotonic accumulation of soot was determined by observation of backpressure increase over $48 \mathrm{~h}$ of the loading phase. The final evaluation of collected soot was performed directly by re-weighing the loaded POC after $48 \mathrm{~h}$ of soot loading, and thus the accumulated mass was calculated. The loaded POCs were then tested under the regeneration phase, which - due to the high temperature of the exhaust gas - allowed

a)

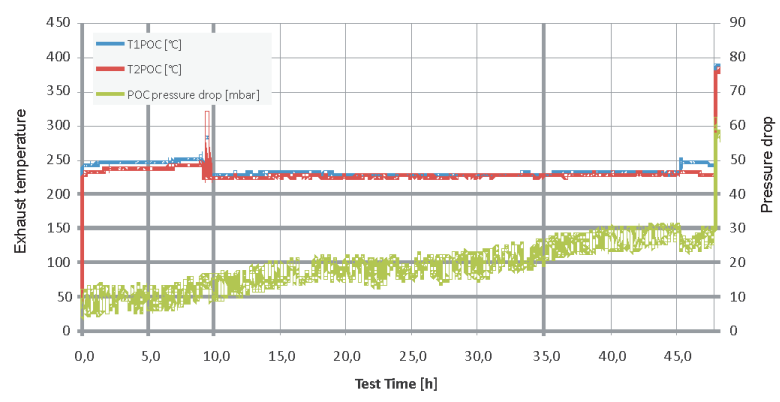

b)

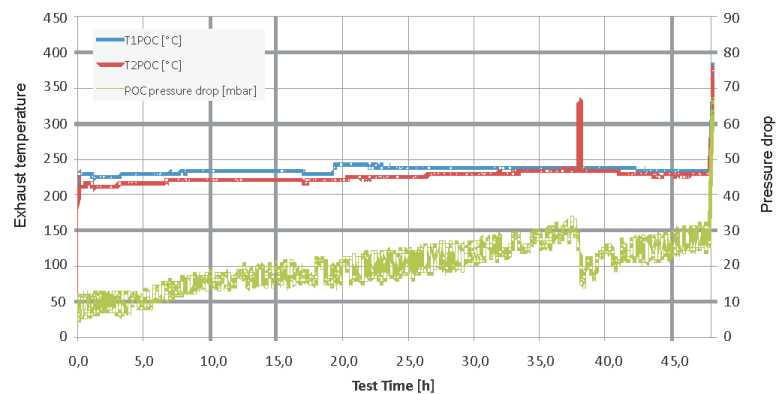

c)

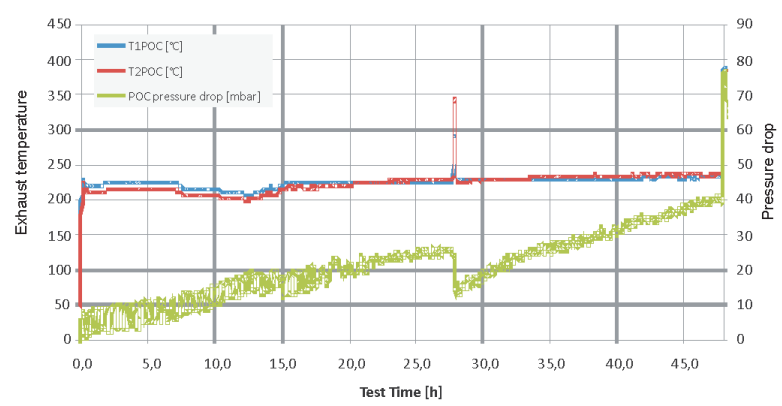

the POC to regenerate. The phenomenon of regeneration was observed via continuous acquisition of gaseous emissions, exhaust backpressure and temperature. This phase lasted $1 \mathrm{~h}$ and a stabilization of backpressure decrease was observed upon completion.

\section{Results}

\subsection{Continuous backpressure and temperature monitoring}

Continuous acquisition of gas pressures and temperatures was conducted for each of the three cycles. The pressure drop over the DOC+POC was determined by two pressure sensors placed upstream and downstream of the sample. Together with the pressure sensors, thermocouples were installed in order to measure both temperatures. Figure 3 shows the results obtained for all three fuels.

The 48 hours of soot loading resulted in a significant increase in the backpressure upstream of the POC, as shown in Figure 3. Although engine load and speed remained the same for the $48 \mathrm{~h}$ loading phase, the exhaust gas temperature was affected by the changes in backpressure. Temperature increases were observed both upstream and downstream of the POC. Figure 3 a shows unexpected peaks in the temperature upstream of the POC after $10 \mathrm{~h}$ of soot loading and Figures $3 \mathrm{~b}$ and $3 \mathrm{c}$ show peaks after $35 \mathrm{~h}$ and $25 \mathrm{~h}$. The temperature rises were
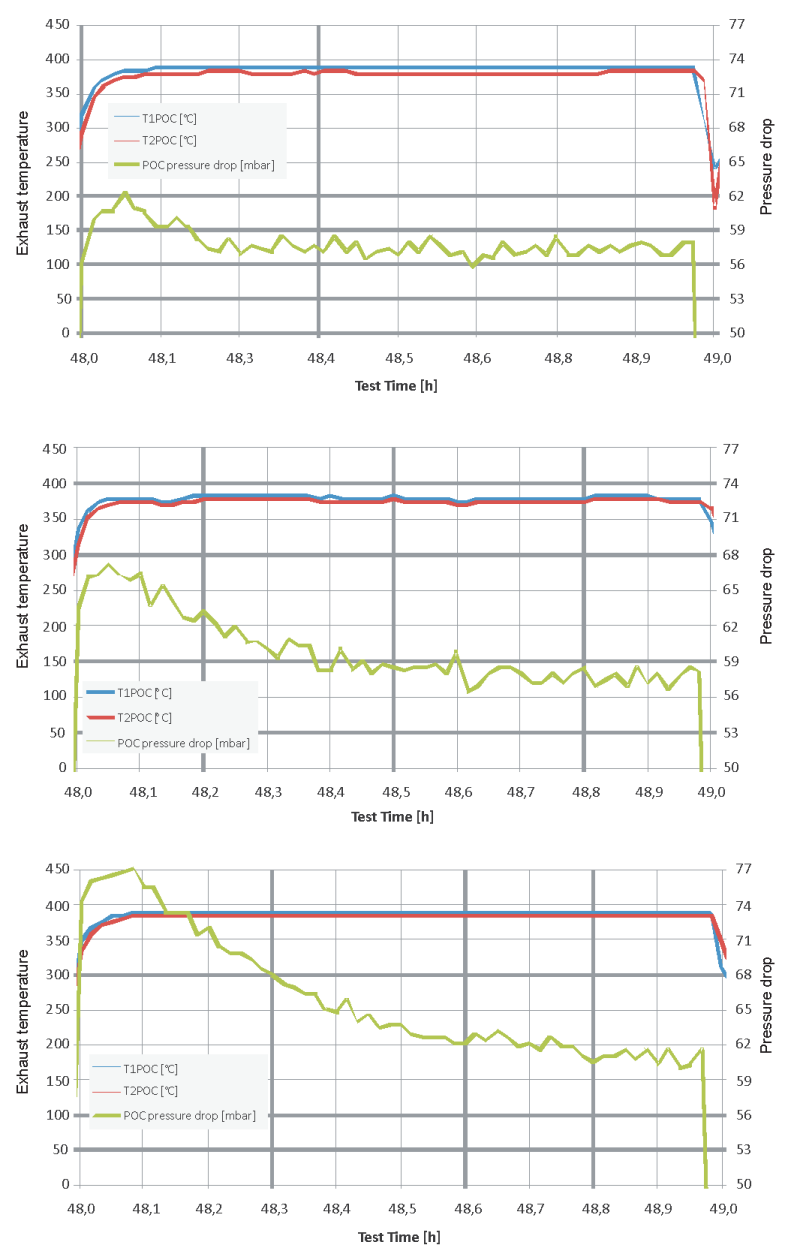

Fig. 3. Backpressure and temperature changes during the loading and regeneration phases for all three fuels: a) S6, b) S65, c) S340; T1POC - temperature upstream of the DOC, T2POC - temperature downstream of the POC 
caused by the uncontrolled behaviour of the engine's EGR valve. The peaks exceeded $250{ }^{\circ} \mathrm{C}$, which resulted in the rapid burning of accumulated soot, rapid growth of the temperature downstream of the POC system and a reduction in backpressure. However, a clear correlation between backpressure and temperature can be observed, apart from in the vicinity of the deviation. The fuel sulphur content significantly influenced the backpressure growth rate and, consequently, the POC pressure drop. An increase of $20 \mathrm{mbar}$ in pressure drop was observed for the S6 fuel, 20 mbar for S65 and 35 mbar for S340, as shown in Figure 3. The pressure drop increase corresponds to the amount of accumulated matter, which was proved by the direct weighing of the POC system.

Immediately after the loading phase, the engine operating point was changed to a higher load and speed resulting in an increase in exhaust temperature and mass flow. The exhaust gas temperature was nearly $400{ }^{\circ} \mathrm{C}$, causing passive regeneration of the POC. The temperature remained stable during the entire regeneration phase, whilst the pressure drop changed as the POC was being cleansed of soot. The shape of the backpressure trace was observed to differ, depending on the accumulated soot and the regeneration temperature. Stabilisation occurred first after $0.3 \mathrm{~h}$ on S6 fuel (visible in Fig. 3a). A similar stabilisation was observed on S65 fuel whilst the backpressure was still visibly decreasing even after $1 \mathrm{~h}$ on S340 fuel, as shown in Figure 3c. During the one hour regeneration, the highest average regeneration rate occurred in the POC loaded with exhaust from combustion of the S340 fuel. The S6 and S65 regeneration rates reached respectively lower values in terms of pressure drop.

\subsection{Soot accumulation}

Example high-resolution transmission electron microscope (HR-TEM) images of emitted soot particles collected during the loading phase with the S340 fuel are presented in Figure 4.The particle sample was first diluted with a single ejector diluter (DR 10) and, then the sample particles were conducted through a tube furnace at a temperature of approximately $700{ }^{\circ} \mathrm{C}$, in order to remove the volatiles from the soot particles. The particles were collected on holey carbon-coated copper TEM grids by first charging them with a corona charger and then collecting the particles with an electric field. As can be seen from Figure 4a, the particles collected were carbon agglomerates consisting of spherical primary particles. Most of the primary particles were roughly $20 \mathrm{~nm}$ in diameter. Figure $4 \mathrm{~b}$ presents the fine structure of soot agglomerates. The figure shows that individual graphene layers, (i.e. the consecutive thin black and white lines in the soot particles), can be observed within the soot structure. The graphene layers tend to be longer and more organized near the edges of the primary particles. In the center of the primary particles, fewer organized graphene layers can be seen as the particle fine structure is more amorphous. Overall, the soot agglomerates emitted are quite typical in terms of particle structure. Similar structures of soot particles have been reported before, for example, by Happonen et al. (2010) [28] with a heavy-duty off-road diesel engine and by Su et al. (2004) [29] with a heavy-duty Euro IV diesel engine.

All three samples of the DOC+POC were fresh before testing. Each unit was weighed before the loading phase in order to establish a reference weight for further weighing. After $48 \mathrm{~h}$ of soot accumulation, the samples were removed from the engine exhaust line and weighed hot on a portable balance with a resolution of $0.5 \mathrm{~g}$. After the weighing, the samples were remounted on the exhaust line. Before starting the regeneration phase, the samples were conditioned at the engine load of the loading phase until all parameters were
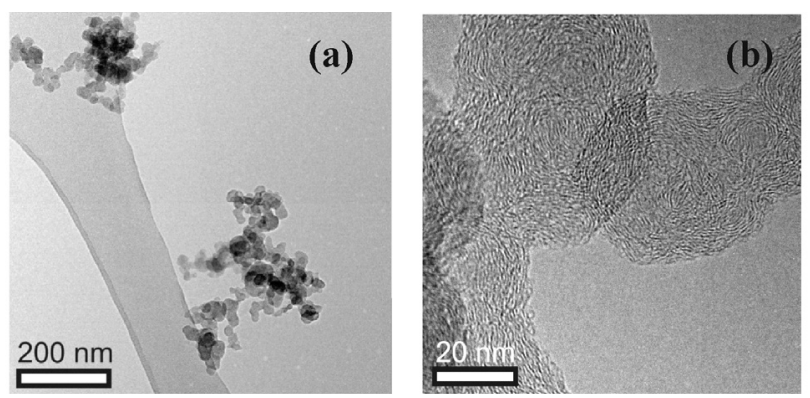

Fig. 4. Example soot particles collected during the loading phase with the S340 fuel. Both an overview of two soot agglomerates (a) and some of the fine structure of soot (10x) (b) are presented

stabilized. The calculated difference was $6 \mathrm{~g}$ for S6 fuel, $10 \mathrm{~g}$ for S65 and $38 \mathrm{~g}$ for S340. The results are shown in Table 1. The filter smoke number (FSN) (measured downstream of the POC at the beginning of the loading phase) increased proportionally with fuel sulphur content (Tab. 1).

Table 1. PM mass in POC and FSN for three types of fuel

\begin{tabular}{|l|c|c|c|}
\hline Type of fuel & S6 & S65 & S340 \\
\hline Mass of accumulated matter [g] & 6 & 10 & 38 \\
\hline $\begin{array}{l}\text { Filter smoke number (FSN) at } \\
\text { The beginning of loading phase }\end{array}$ & 0.35 & 0.53 & 0.67 \\
\hline
\end{tabular}

The shapes of the particle reduction efficiency curves (Fig. 5) were similar to the ones observed for heavy duty diesel engine applications $[32,33]$; the highest reduction efficiencies were observed at the smallest particle sizes and the reduction efficiency decreased from $\sim 60 \%$ at $15 \mathrm{~nm}$ to $\sim 30 \%$ at $100-$ $200 \mathrm{~nm}$. After 20 hours of engine operation, the shapes of the reduction efficiency curves were similar for each fuel. However, after 40 hours, the reduction efficiency was slightly higher with the S6 fuel compared to the S65 and S340 fuels.

The nonvolatile particle reduction efficiencies with the $\mathrm{DOC}+\mathrm{POC}$ were studied during both driving phases, and the results are presented in Figure 6. The engine load affected the soot particle concentrations and their reduction within the DOC+POC; the particle number concentrations were approximately 4 times higher during the regeneration and the reduction efficiency was also increased. The soot number reduction was $\sim 50 \%$ during the regeneration phase compared to $30-40 \%$ observed during the loading phase. The differences are caused by flow pattern changes in the DOC $+\mathrm{POC}$ system; exhaust temperature and the flow face velocity of the DOC + POC increased from $\sim 240{ }^{\circ} \mathrm{C}$ to $\sim 380{ }^{\circ} \mathrm{C}$ and from 2 $\mathrm{m} / \mathrm{s}$ to $10 \mathrm{~m} / \mathrm{s}$, respectively, as the load was increased from the light to the medium load point. 


\subsection{Gaseous emissions}

Engine-out and postDOC + POC gaseous emissions of THC, $\mathrm{CO}, \mathrm{NO}_{\mathrm{x}}$ and $\mathrm{NO}$, were measured during the loading phase, with the exhaust gas temperature below $250{ }^{\circ} \mathrm{C}$. The dependency of catalyst efficacy on temperature is widely recognised; low temperatures enhance the influence of the fuel on catalyst efficiency and make the drawing of conclusions clearer.

Calculated values of the catalyst conversion efficiency are shown in Figure 7. The engine-out emission of $\mathrm{NO}_{x}$ was found not to be affected by FSC; as all pre-DOC emissions of $\mathrm{NO}_{\mathrm{x}}$ remained at a similar level. Nevertheless, an influence of FSC on the $\mathrm{NO}_{2} /$ $\mathrm{NO}_{x}$ ratio in the raw exhaust was observed. The experiment confirmed the minor impact of usage of a DOC+POC on $\mathrm{NO}_{x}$ emission. However, $\mathrm{NO}_{2}$ emission was significantly affected.

All measurements confirmed the decrease of $\mathrm{NO}_{2}$ downstream of the $\mathrm{DOC}+\mathrm{POC}$, which was named $\mathrm{NO}_{2}$ consumption. The intensity of this phenomenon was calculated according to (1) - the same formula used for evaluation of the conversion efficiency of other pollutants:

$$
\mathrm{NO}_{2} \text { consumption }=\frac{\mathrm{NO}_{2} \text { preDOC }-\mathrm{NO}_{2} \text { postPOC }}{\mathrm{NO}_{2} \text { preDOC }} \times 100 \%
$$

During the regeneration phase, the research focused on the emission of nitrogen oxides and hydrocarbons, as shown in Figure 8. The blue trace shows THC emission and for all

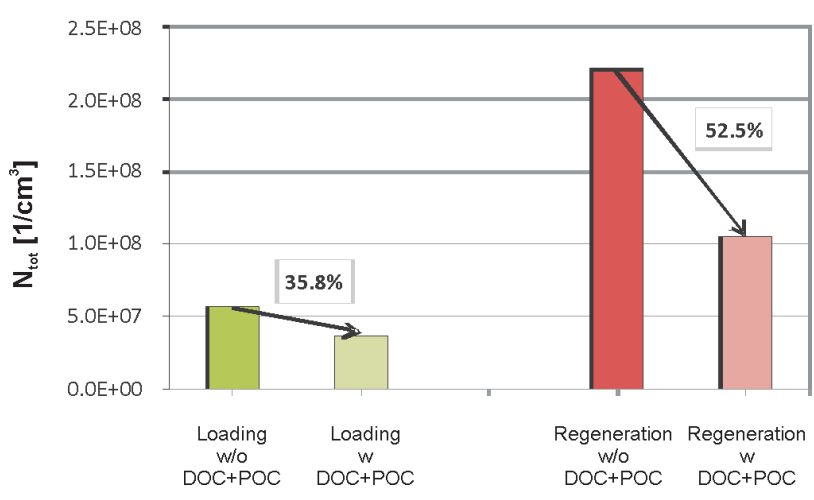

Fig. 6. Soot particle number concentrations upstream (w/o )and downstream (w) of the DOC+POC during the loading (low load) and regeneration (medium load) phases ( $\mathrm{S} 6 \mathrm{fuel}$ ). The percentages indicate the particle number reduction effected by the $\mathrm{DOC}+\mathrm{POC}$
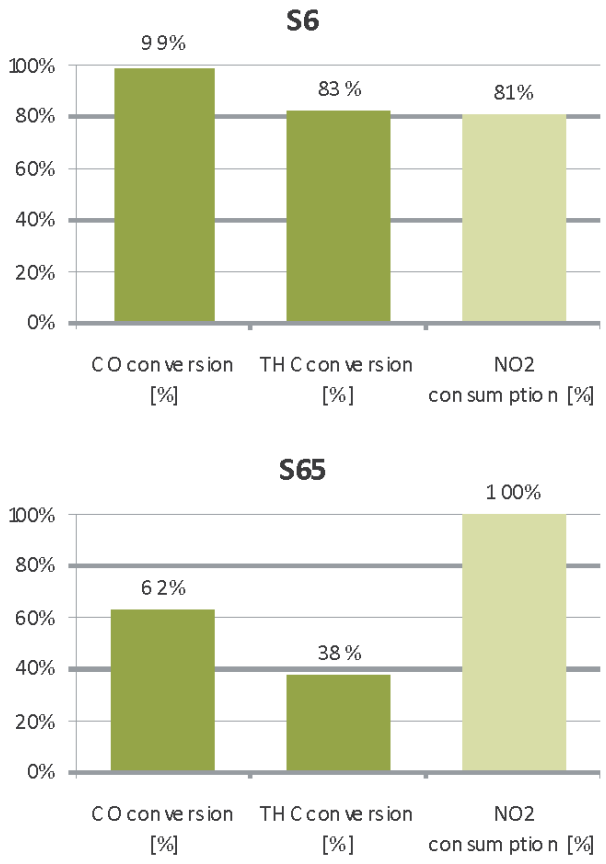

$\mathbf{S 3 4 0}$

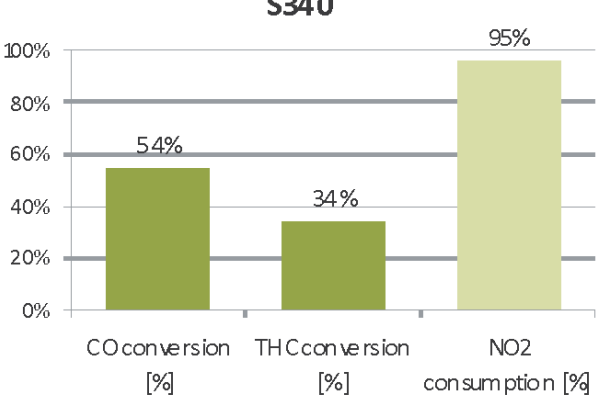

Fig. 7. DOC + POC conversion efficiency for different fuels

three tests the emission decreased, with some fluctuation for S340 at the beginning. Shown in orange, the emission of $\mathrm{NO}$ - and presumably the consequential $\mathrm{NO}_{\mathrm{x}}$ emission increased for the first $0.1 \mathrm{~h}(6 \mathrm{~min})$ but soon stabilised as the temperature in the combustion chamber achieved a certain level. The brown line shows a direct $\mathrm{NO}_{\mathrm{x}}$ measurement and it is to be considered the background for the $\mathrm{NO}_{2}$ emission.

\subsection{Particulate matter measurements}

The main focus of the research was to evaluate the POC performance of PM emission reduction against gradual levels of its loading and during high temperature regeneration. Therefore, an AVL SMART SAMPLER SPC 472 was used in order to measure PM emission downstream of the POC. The results obtained during the loading phase are shown in Figure 9. PM emission increased as the loading phase advanced for fuels S65 and S340; for S6 fuel emissions were similar at the beginning and end of the phase. The results indicate that POCs coping with high FSC fuels are loaded earlier, and that their ability to absorb PM is diminished. For that reason, the intervals between high temperature regenerations should get shorter as the sulphur level in fuel increases. The regeneration 
phase lasted $60 \mathrm{~min}$ and two 20 min measurements of PM were then performed. The first one started together with the
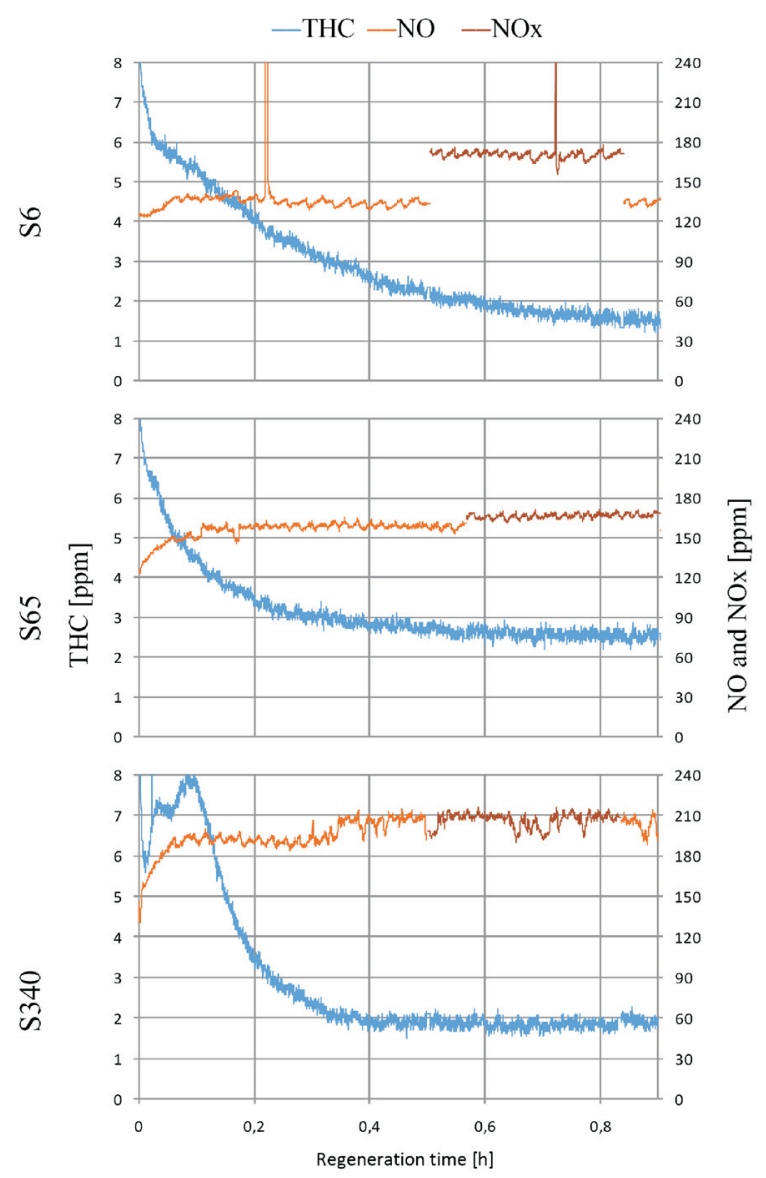

Fig. 8. Gaseous emission of THC, NO and NOx during the regeneration phase

beginning of the regeneration phase and the next one started 20 min later, as shown in Figure 10. The results obtained confirm the dependence of PM emission on the fuel sulphur content, as PM emission increased proportionally with sulphur mass concentration. In all cases, emission measured during the second 20 min of regeneration was lower. This proves that either the loaded POC's emission reduction capability is lower during the first $20 \mathrm{~min}$ of regeneration, or some of the accumulated matter is being blown out of the POC due to the increased exhaust gas flow rate.

\section{Discussion}

The negative impact of high-sulphur fuels on emissions was determined some years ago. Sulphur harms the environment in several ways. The direct products of burnt sulphur are sulphur dioxide $\left(\mathrm{SO}_{2}\right)$ and sulphur-based particulate matter. Moreover, its poisonous influence on catalysts decreases the conversion efficiencies of $\mathrm{THC}, \mathrm{CO}$ and $\mathrm{NO}_{\mathrm{x}}$ (for gasoline engines) and tailpipe emissions consequently increase. The reduced oxidative ability of the catalyst also decreases the conversion of $\mathrm{NO}$ to $\mathrm{NO}_{2}$, which requires a higher regeneration temperature for the particulate filter. However, sulphur is a naturally occurring component of crude oil and remains in diesel and gasoline fuels unless additional effort is expended to ensure its elimination. Western countries decided to gradually decrease the fuel sulphur content by applying further technological efforts in fuel production. The current limit in the EU is 10 ppm. In developing countries, the fuel quality and emission limits are continually becoming stricter, but there are still relatively high contents of sulphur in diesel fuel. Although most countries declare their intention to reduce the amount of sulphur in fuel in the future, in the meantime, emissions can be reduced by aftertreatment devices and development engine control, such that the system is equipped to cope with high sulphur fuels.

In this case, the research efforts must focus on simple and reliable solutions that cope with sulphured fuels and can be accepted by developing countries, especially in terms of cost. The fulfilment of these requirements is the aim of the POC. The S340 exhaust gas contains significantly more PM than S6 exhaust, which can be indirectly read from Table 1 . This study has confirmed the POC's capability in terms of collect-

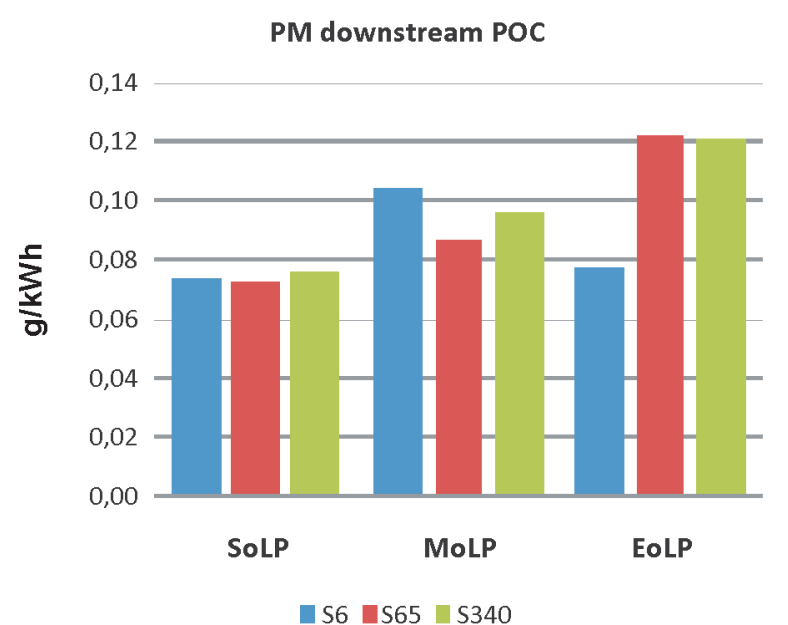

Fig. 9. PM emission at various stages of the loading phase; S/M/EoLP Start/Middle/End of Loading Phas

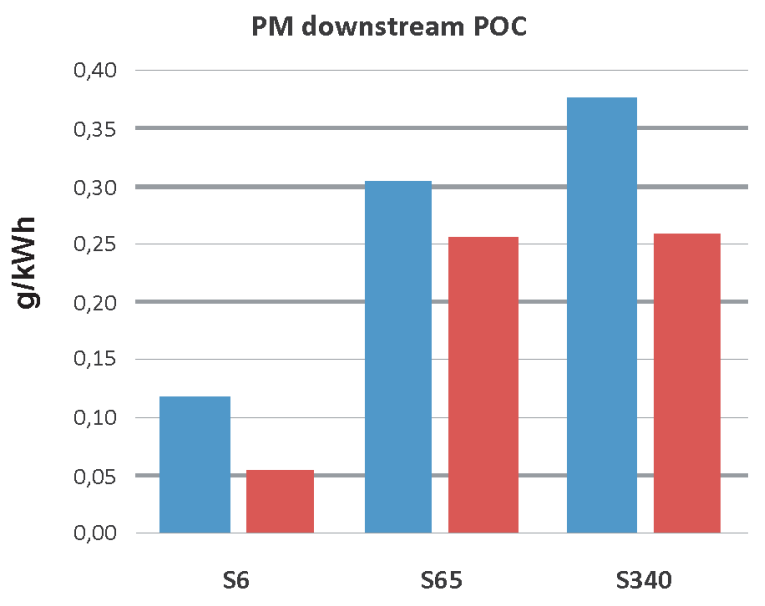

Fig. 10. PM emission at regeneration phase; blue bars - measurement during the first $20 \mathrm{~min}$ of the regeneration phase; red bars - measurement during the second 20 min of the regeneration phase 
ing PM and, as a result, decreasing tailpipe PM emissions. As predicted, the sulphur decreased the effectiveness of THC and $\mathrm{CO}$ conversion at temperatures below $250{ }^{\circ} \mathrm{C}$, as shown in Figure 7. However, the conversion at higher temperatures was not strongly affected. Weighing measurements indicated strong effects of the FSC on the accumulated material in the DOC+POC. However, there was no significant difference in the engine out soot particle emissions and soot reduction efficiency between the fuels. This indicates that sulphur based material is also accumulated in the $\mathrm{DOC}+\mathrm{POC}$, by adsorption on the washcoat or on the accumulated particles. The adsorption sulphur onto the washcoat of the DOC affects the reduction of gaseous pollutants.

\section{Conclusions}

The purpose of this study was to investigate the impact of sulphur containing fuels on POC catalyst operation and extend current understanding. Low exhaust temperature loading followed by regeneration events especially reflects the performance of $\mathrm{DOC}+\mathrm{POC}$ in passenger cars in urban driving conditions in metropolitan cities, where high sulphur fuel and very low exhaust gas temperatures simultaneously cause additional challenges. The analysis of the test results permitted the following conclusions to be drawn:

- The amount of matter collected and the corresponding pressure drop over the system depends on the sulphur level in the diesel fuel. PM accumulation during the loading phase is proportional to the fuel sulphur level.
- The regeneration of POCs with higher soot loads results in higher PM emission.

- Tailpipe PM emission during regeneration is always higher at the beginning of the phase than in the later stages of the phase.

- Elevated exhaust temperatures (up to approx. $400{ }^{\circ} \mathrm{C}$ ) affect total cleansing of the system from soot for all three fuel types, although the recovery time differs and depends on the fuel type.

- For proper understanding of gaseous emissions, it is crucial to compare the data collected at the same temperature; for this reason, each measurement was performed under the following conditions: at $207^{\circ} \mathrm{C}$; at $50 \mathrm{Nm}$ (with temperature determined by engine load); and at $245^{\circ} \mathrm{C}$.

- The ability of the DOC+POC to convert $\mathrm{CO}, \mathrm{HC}$ and $\mathrm{NO}_{\mathrm{x}}$ increases with the exhaust temperature.

- The particle reduction efficiency of the DOC $+\mathrm{POC}$ is dependent on particle size and exhaust flow velocity \& temperature.

- $\mathrm{NO}_{2}$ emission during the loading phase is higher in the engineout exhaust than downstream of the POC. $\mathrm{NO}_{2}$ conversion ranged from $83 \%$ up to $100 \%$ for S65 and S340 fuels, with no temperature dependency observed. A strong temperature dependency was observed for S6, resulting in a conversion drop from $74 \%$ at $207^{\circ} \mathrm{C}$ to $1 \%$ and $8 \%$ at $245^{\circ} \mathrm{C}$.

Periodical random movement of the EGR valve was observed during the loading phase, causing short-term rises in the exhaust gas temperature, resulting in a partial burn-out of collected soot.

\section{Acknowledgements}

Professor L. Reine Wallenberg and the nCHREM of Lund University are acknowledged for enabling HR-TEM imaging.

\section{Badania charakterystyki pracy reaktora katalitycznego utleniającego cząstki stałe (POC) oraz zjawiska formowania się cząstek stałych dla olejów napędowych z różną zawartością siarki}

W artykule opisano analizę ogólnego wpływu olejów napędowych z duża zawartościa siarki na pracę reaktora katalitycznego utleniającego cząstki state (POC), skupiając się głównie na redukcji masy i liczby cząstek statych i zdolności regeneracji reaktora po nagromadzeniu się w nim sadzy. Podstawa do przeprowadzenia badan opisanych w tej pracy jest występowanie oleju napędowego o wysokiej zawartości siarki w krajach rozwijających się, szczególnie w Azji. Podwyższona zawartość siarki skutkuje wzrostem emisji cząstek stałych, co stawia dodatkowe wymagania układom oczyszczania spalin. Jako prostą i niedroga metodę ograniczania szkodliwej emisji stosuje się reaktor utleniajacy POC, który dzięki swej bezobstugowej konstrukcji pozwala jest możliwy do zastosowania nawet w użytkowanych już pojazdach. Przeprowadzone badania na paliwach o wysokiej zawartości siarki potwierdzity pozytywny wplyw zastosowania reaktor POC na poziom emisji cząstek stałych oraz jego bezawaryjność nawet przy wysokim poziomie załadowania sadza.

Badania przeprowadzono na silniku zamontowanym na stanowisku hamownianym w Zakładzie Badań Silników Instytutu BOSMAL w Bielsku-Białej. Do pomiarów emisji gazowych składników spalin wykorzystano zestaw analizatorów Horiba Mexa 7000, a stopień zadymienia spalin (FSN) mierzono za pomoca urzadzenia AVL Smoke Meter. Pomiary liczby i średnic cząstek statych byly wykonywane przez specjalistów z Tampere Technical University przy zastosowaniu specjalistycznych urządzén pomiarowych z firm TSI i Dekati.

Badania wykonywano dla olejów napędowych o trzech różnych zawartościach siarki: 6, 65 i 340 ppm. Wyniki badań przedstawione $w$ artykule daja ogólny pogląd na specyfikę i problemy zwiazane z zastosowaniem reaktora POC do układu wydechowego silnika o zapłonie samoczynnym zasilanego paliwami o podwyższonej zawartości siarki. Metodyka badań została ustalona eksperymentalnie i przeprowadzona na reaktorach POC wspótpracujacych z silnikiem o zaptonie samoczynnym wyposażonym w układ zasilania common rail oraz spetniajacych normę emisji Euro 4. Każde paliwo byto testowane na identycznym, nowym reaktorze POC podtaczonym do reaktora utleniającego DOC, który stanowit podstawowe wyposażenie badanego silnika. 
Pierwsza faza testu, zwana faza załadowania, obejmowała 48 godzin pracy ciagłej silnika w ustalonym punkcie, w którym temperatura spalin, mierzona na wejściu do reaktora nie przekraczała $250{ }^{\circ} \mathrm{C}$. Miało to na celu zasymulowanie skrajnie trudnych warunków pracy układu w intensywnym ruchu miejskim i nagromadzenie jak największej ilości sadzy wewnątrz reaktora POC. Powyższe warunki utrudniaja lub wręcz uniemożliwiają zajście procesu regeneracji pasywnej POC.

Druga faza testu - regeneracji, obejmowała analogiczna prace silnika w czasie 1 godziny, przy czym temperatura spalin została podwyższona $i$ wynosita $400^{\circ} \mathrm{C}$. W takich warunkach pracy obserwowano proces i czas samooczyszczenia się POC podczas regeneracji pasywnej z nagromadzonych wcześniej czastek stałych.

Ilość zgromadzonej sadzy, w fazie załadowania, określana była za pomoca ciagłego pomiaru ciśnienia statycznego spalin przed i za POC. Intensywność wzrostu ciśnienia narastała wraz ze wzrostem zawartości siarki w paliwie. Po zakończeniu fazy załadowania wszystkie egzemplarze POC zostały zważone i potwierdzity się obserwacje wynikajace ze wzrostu ciśnienia. Badania wykazały pogorszenie sprawności konwersji składników gazowych, takich jak węglowodory (THC) oraz tlenek węgla (CO) w temperaturze poniżej $250^{\circ} \mathrm{C}$ wraz ze stopniem załadowania POC czastkami stałymi. Jak przypuszczano, nie wykazano znaczacego wpływu reaktora na ogólna emisję tlenków azotu (NO,). Zaobserwowano natomiast zwiększenie udzialu tlenku azotu $(N O)$ w sumarycznym bilansie $\left(N_{\chi}\right)$ za reaktorem POC. Zdolność reaktora do konwersji THC oraz CO wzrasta w sposób znaczący przy temperaturze spalin $400{ }^{\circ} \mathrm{C}$, która wybrana zostata do regeneracji POC. Oczyszczaniu reaktora w początkowej fazie towarzyszy wzrost emisji cząstek statych, który spada wraz z postępem procesu oczyszczania. Stwierdzono również znaczący wzrost redukcji suchych cząstek do około $50 \%(27$ - 38\% dla spalin o niskiej temperaturze $w$ fazie załadowania).

Słowa kluczowe: reaktor katalityczny utleniający czątki stałe (POC), zawartość siarki w oleju napędowym, redukcja cząstek statych, regeneracja

Paper reviewed/Artykut recenzowany

\section{Bibliography}

[1] Bielaczyc P., Keskinen J., Dzida J., Sala R. et al.: Performance of Particle Oxidation Catalyst and Particle Formation Studies with Sulphur Containing Fuels, SAE Int. J. Fuels Lubr. 5(2),2012, doi:10.4271/2012-01-0366.

[2] Dockery D., Pope A., Xu X., Spengler J., Ware J., Fay M., Ferris B., Speizer F.: An Association between Air Pollution and Mortality in Six U.S. Cities. The New England Journal of Medicine 1993, 329, 1753-1759.

[3] Pope C., Burnet R., Thun M., Calle E., Krewski D., Ito K., Thurston G.: Lung cancer, cardiopulmonary mortality, and long-term exposure to fine particulate air pollution. The Journal of the American Medical Association 2002, 287, 1132-1141.

[4] Peters A., Dockery D., Muller J., Mittleman M.: Increased particulate air pollution and the triggering of myocardial infarction. Circulation 2001, 103, 2810-2815.

[5] Ghi A., Kim C., Devlin R.: Concentrated ambient air particles induce mild pulmonary inflammation in healthy human volunteers. American Journal of Respiratory Critical Care Medicine 2000, 162, 981-988.

[6] Saldiva P., Clarke R., Coull, Stearns R., Lawrence J., Murthy G., Diaz E., Koutraki P., Suh H.,Tsuda A., Godlesi J.: Lung inflammation induced by concentrated ambient air particles is related to particle composition. American Journal of Respiratory and Critical Care Medicine 2002, 165, 1610-1617.

[7] Dybdahl M., Risom L., Bornholdt J., Autrup H., Loft S., Wallin H.: Inflammatory and genotoxic effects of diesel particles in vitro and in vivo. Mutation Research 2004, 562, 119-131.

[8] Mazzarella G., Ferraraccio F., Prati M., Annunziata S., Bianco A., Mezzogiorno A., Liguori G., Angelillo I., Cazzola M.: Effects of diesel exhaust particles on human lung epithelial cells: An in vitro study. Respiratory Medicine 2007, 101, 1155-1162.

[9] Crüts B., Etten L., Törnqvist, H., Blomberg A., Sandstöm T., Mills N., Borm P.:Exposure to diesel exhaust induces changes in EEG in human volunteers. Particle and Fibre Toxicology 2008, 5, 4.

[10] Bielaczyc P., Merkisz J., Kozak M.: Analysis of the Influence of Fuel Sulphur Content on Diesel Engine Particulate Emissions, SAE Technical Paper 2002, 2002-01-2219.
[11] Bielaczyc P., Kozak M., Merkisz J.: Effects of Fuel Properties on Exhaust Emissions from the Latest Light-Duty DI Diesel Engine, JSAE 20030355, SAE Technical Paper 2003, 200301-1882.

[12] Kittelson D.B.: Engines and nanoparticles: a review, Journal of Aerosol Science 1998, 29, 5-6, 575-588.

[13] Heikkilä, J., Virtanen, A., Rönkkö, T., Keskinen, J., Aakko-Saksa, P., Murtonen, T. Nanoparticle Emissions from a Heavy-Duty Engine Running on Alternative Diesel Fuels, Environmental Science \& Technology 2009, 43, 9501-9506.

[14] Rönkkö T., Virtanen A., Vaaraslahti K., Keskinen J., Pirjola L., Lappi M.: Effect of dilution conditions and driving parameters on nucleation mode particles in diesel exhaust: Laboratory and on-road study. Atmospheric Environment 2006, 40, 28932901.

[15] Vogt R., Scheer V., Casati R., Benter T.: On-Road Measurement of Particle Emission in the Exhaust Plume of a Diesel Passenger Car. Environmental Science and Technology 2003, 37, 4070-4076.

[16] Rönkkö T., Virtanen A., Kannosto J., Keskinen J., Lappi M., Pirjola L.: Nucleation mode particles with a nonvolatile core in the exhaust of a heavy duty diesel vehicle. Environmental Science and Technology 2007, 41, 6384-6389.

[17] Filippo A.D., Maricq M.M. : Diesel Nucleation Mode Particles: Semi-volatile or Solid? Environmental Science and Technology 2008, 42, 7957-7962.

[18] Uhrner U., von Löwis S., Vehkamäki H., Wehner B., Bräsel S., Hermann M., Stratmann F., Kulmala M., Wiedensohler A.: Dilution and aerosol dynamics within a diesel car exhaust plume-CFD simulations of on-road measurement conditions. Atmospheric Environment 2007, 41, 7440-7461.

[19] Lemmetty M., Pirjola L., Rönkkö T., Virtanen A., Keskinen J.: The effect of sulphur in diesel exhaust aerosol: models compared with measurements. Aerosol Science and Technology 2008, 42, 916-929.

[20] Maricq M., Chase R., Xu N., Laing P.: The Effects of the Catalytic Converter and Fuel Sulfur Level on Motor Vehicle Particulate Matter Emissions: Light Duty Diesel Vehicles. Environmental Science and Technology 2002, 36, 283-289. 
[21] Schneider J., Hock N., Weimer S., Borrmann S., Kirchner U., Vogt R., Scheer V.: Nucleation Particles in Diesel Exhaust: Composition Inferred from In Situ Mass Spectrometric Analysis. Environmental Science and Technology 2005, 39, 6153-6161.

[22] Lehtoranta K., Matilainen P., Åsenbrygg J.M., Lievonen A., Kinnunen T.J.J.: Particle Oxidation Catalyst in Light Duty and Heavy-Duty Diesel Applications. Society of Automotive Engineers (SAE) Technical Paper 2007, 2007-24-0093.

[23] Lehtoranta K., Matilainen P., Kinnunen T.J.J., Heikkilä J., Rönkkö T., Keskinen J.: Diesel Particle Emission Reduction by a Particle Oxidation Catalyst. Society of Automotive Engineers (SAE) Technical Paper 2009,2009-01-2705.

[24] Lähde T., Rönkkö T., Happonen M., Söderström C., Virtanen A., Solla A., Kytö M., Rothe D., Keskinen J.: Effect of Fuel Injection Pressure on a Heavy-Duty Diesel Engine Non-volatile Particle Emission. Environ. Sci. Technol. 2011.

[25] Karjalainen P., Heikkilä J., Rönkkö T., Keskinen J., Lehtoranta K., Matilainen P., Kinnunen T.: Effect of Exhaust Flow Condi-

Jorma Keskinen, DEng. - professor, Head of Department of Physics, Tampere University of Technology, Finland.

Drinż. Jorma Keskinen - profesor, Dyrektor Instytutu Fizyki Politechniki w Tampere, Finlandia.

e-mail: jorma.keskinen@tut.fi

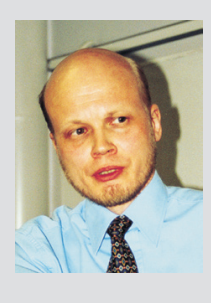

Panu Karjalainen, MEng. - researcher in Aerosol Physics Laboratory, Department of Physics, Tampere University of Technology, Finland.

Mgr inż. Panu Karjalainen - pracownik badawczy w Laboratorium Fizyki Aerozoli w Instytucie Fizyki Politechniki w Tampere, Finlandia.

e-mail: panu.karjalainen@tut.fi

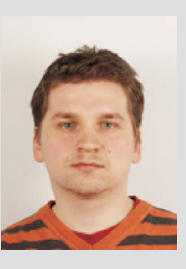

Piotr Bielaczyc, DEng. - head of the Engine Research Department, BOSMAL Automotive Research and Development Institute Ltd in Bielsko-Biała.

Dr inż. Piotr Bielaczyc - kierownik Zakładu Badań Silników, Instytut Badań i Rozwoju Motoryzacji BOSMAL Sp. z o.o., Bielsko-Biała.

e-mail:piotr.bielaczyc@bosmal.com.pl

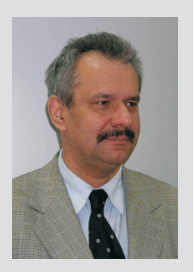

Jakub Dzida, MEng. - research Engineer in Engine Research Department, Bosmal Automotive Research \& Development Institute Ltd, Bielsko-Biała.

Mgr inż. Jakub Dzida - inżynier badawczy w Laboratorium Badań Silników Instytutu Badań i Rozwoju Motoryzacji BOSMAL w Bielsku-Białej.

e-mail: jakub.dzida@bosmal.com.pl

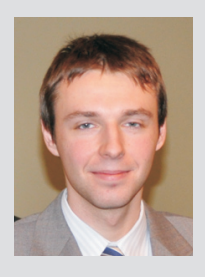

Pekka Matilainen, MSc. - senior Researcher of Physics in EcocatOy, Finland.

Mgr Pekka Matilainen-starszy pracownik badawczy $w$ dziedzinie fizyki w firmie EcocatOy w Finlandii. e-mail:pekka.matilainen@ecocat.com tions and External Cooling on the Performance of the Particle Oxidation Catalyst (POC), SAE Technical Paper Series 2010, 2010-01-2158.

[26] Wang S.C., Flagan R.C.: Scanning Electrical Mobility Spectrometer, Aerosol Science and Technology 1990, 13, 230-240.

[27] Chen D.R., Pui D., Hummes D., Fissan H., Quant F., Sem G.: Design and Evaluation of a Nanometer Aerosol Differential Mobility Analyzer (Nano-DMA), J. Aerosol Sci.1998, 29, 497-509.

[28] Happonen M., Lähde T., Messing M.E., Sarjovaara T., Larmi M., Wallenberg L.R., Virtanen A., Keskinen J.: The comparison of particle oxidation and surface structure of diesel soot particles between fossil fuel and novel renewable diesel fuel, Fuel 2010, 89, 4008-4013.

[29] Su D.S., Müller J.O., Jentoft R.E., Rothe D., Jacob E., Schlögl R.: Fullerene-like soot from Euro IV diesel engine: consequences for catalytic automotive pollution control. Topics in Catalysis 2004, 30 (1), 241-245.

Topi Rönkkö, DEng. - lecturer in Department of Physics, Tampere University of Technology, Finland.

Dr inż.Topi Rönkkö - wykładowca w Instytucie Fizyki Politechniki w Tampere, Finlandia.

e-mail: topi.ronkko@tut.fi

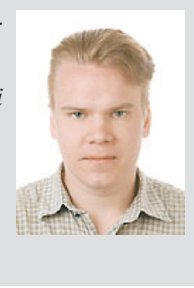

Matti Happonen, MEng. - researcher in Aerosol Physics Laboratory, Department of Physics, Tampere University of Technology, Finland.

Mgr inż. Matti Happonen - pracownik badawczy w Laboratorium Fizyki Aerozoli w Instytucie Fizyki Politechniki w Tampere, Finlandia.

e-mail:matti.happonen@tut.fi

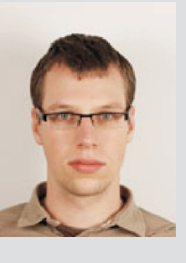

Rafal Sala, MEng. - research Engineer in Engine Research Department, Bosmal Automotive Research \& Development Institute Ltd, Bielsko-Biała, Poland.

Mgr inż. Rafat Sala - inżynier badawczy w Laboratorium Badań Silników Instytutu Badań i Rozwoju Motoryzacji BOSMAL w Bielsku-Białej.

e-mail: rafal.sala@bosmal.com.pl

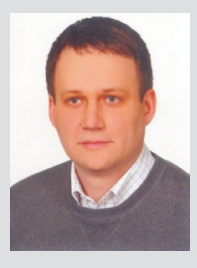

Toni Kinnunen, PhD. - chief Technology Officer (CTO) in EcocatOy, Finland.

Dr Toni Kinnunen -dyrektor ds. technicznych $w$ firmie EcocatOy w Finlandii.

e-mail: toni.kinnunen@ecocat.com

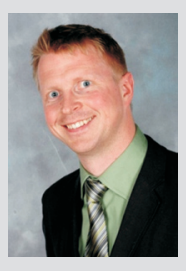

Maria E Messing, PhD. - postdoctoral fellow in Solid State Physics/Synchrotron Radiation Research, Lund University, Sweden.

Dr Maria E. Messing - odbywa staż podoktorski w Laboratorium Fizyki Ciała Stałego i Promieniowania Synchrotronowego Uniwersytetu w Lund w Szwecji. e-mail: maria.messing@ftf.lth.se

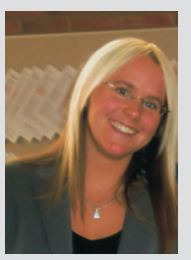

